УДК: 72.036

ББК: 85.113(2)6

A43

DOI: $10.18688 / \mathrm{aa} 200-3-41$

V. Bass

\title{
"Space, Mass, Surface in Architecture": Conceptualization of Spatial Categories and a Building as a Border in Architectural Thought and Practice of the Soviet Constructivism
}

The $\operatorname{article}^{1}$ is a part of the research project studying the professional consciousness of Russian architects of the $20^{\text {th }}$ century, the history of architectural theory and education in Russia and the USSR. Main questions to be addressed are as follows: how were the changing attitudes towards space and form reflected in Soviet Constructivist ${ }^{2}$ architecture conceived as a creative practice and social field? And what were the consequences of this "spatial turn" for the Russian architecture of the $20^{\text {th }}-$ early $21^{\text {st }}$ century?

Trying to answer these questions, I will start with the background part describing the spatial turn in European architectural thought at the beginning of Modernism. Then I will discuss some social and visual aspects of this turn in Soviet architecture of the 1920s. And the final part of the article is the study of the case where all the categories mentioned in the title meet in the Soviet Modernist spatial concept and discourse of form and composition. I will examine the Modernist system of architectural propaedeutics, its establishment in education, its sources, the reasons for its persistence, and some effects of its current topicality.

Modernist "spatial turn" in architectural practice and thought: the background "Space, not stone, is the material of architecture."

N. Ladovsky [15]

The common view in the literature on the establishment of the modern spatial concept ${ }^{3}$ is that the roots of the latter can be found as early as in the Renaissance period. Axial development of space, straight streets and the perception of an existing city, existing urban fabric as a kind of background for the planner were typical of this town-planning practice

Some points and materials discussed have been included in an article published in Russian in "Novoe Literaturnoe Obozrenie" ("New Literary Observer") magazine [1].

2 The term "Constructivism" is here employed in conventional way - as an umbrella term for various Soviet Modernist movements and groups. Since it was also a self-designation of specific movement, it is especially mentioned when "Constructivism" is used in this sense.

3 Built on universal abstraction of homogeneous, regular, infinite space to be delimited and articulated by means of architectural form. 
(see e.g. urban transformation of Rome in the $16^{\text {th }}$ century). Some important examples can be found in $17^{\text {th }}$-century Versailles and then in Paris under Baron Haussmann in the $19^{\text {th }}$ century. Moreover, in the age of Modernity they started considering cities as a superposition of networks and people's trajectories rather than just a set of buildings sharing the same area.

Since the Enlightenment Vitruvian vision of the architect's activity as shaping volumes (similar to ideal bodies) has been giving place to the delimitation of space with surfaces. One should mention French architects and theorists like C.-N. Ledoux ${ }^{4}$, J.-N.-L. Durand's technique of composition based on a system of axes and a grid, and the new, protofunctionalist vision reflected e.g. in Viollet-le-Duc "Discourses" 5 . An architect is the one who organizes your life in functional sense, "the programme" becomes the most important word for a designer, and the exterior of a building is to be derived from its internal structure, its function.

The French Revolution and the end of the Ancien Régime resulted in emergence of public buildings, buildings with "the absent patron" according to Paul Frankl: "In the older church and palace there had been a permanent inhabitant whose actual or supposed relationship to the changing visitors was a fixed and lasting one. Now buildings become shells occasionally used by people who want to be restored to health, to bathe, learn, read, or buy. These buildings cannot be identified with one personality; they belong to everyone and therefore to no one" [5, p. 182]. Flexible structures of exhibition buildings, providing crowds of visitors with a covered space for a short while, illustrate this idea perfectly ${ }^{6}$.

The transformation of the architects' attitudes towards space coincided with the changing spatial agenda in social dimension (or rather was one of the faces of the process). The $19^{\text {th }}$ and early $20^{\text {th }}$ century modernization implied the expansion in space. Conflicts like the Great War made people think in spatial categories visualized e.g. on the war theatre maps. Europeans were gradually getting aware of space and its importance. The early theories and even popular books on the outer space exploration ${ }^{7}$ contributed to this "spatial turn." They imagined the future civilization as one of spatial freedom - see e.g. popular images of multilevel cities of tomorrow. The Avant-garde art was an essential element of this process of spatial emancipation. Freedom of shaping of form and composition, the volumes floating like in outer space were typical of works by K. Malevich, El Lissitzky et $\mathrm{al}^{8}$.

\footnotetext{
4 "If one has satisfied the stakeholders' demands in terms of distribution there is no need to adjust the character of the building exterior according to the severity of architectural orders. This distribution is to be found in the analogy of the surfaces and voids..." ([17, p. 147], transl. by VB).

"The architect has become the master of his programme... His plan settled upon, his elevations are a part and an expression of them; ... the dominating idea of the plan becomes the principal feature of the façades... Then arises under his hand a sort of carcass or frame, a combination of masses, in which he proceeds to make the exterior appearance a manifestation of the interior dispositions, to cause the idea of the plan frankly to reappear in the elevation..." [25, pp. 189-190].

6 One could draw the parallel with R. Ventury's PostModernist concept of "decorated shed," "the elementary shelter with signs".

$7 \quad$ Like K. Tsiolkovsky's “Exploration of Outer Space by Means of Rocket Devices" (1 $1^{\text {st }}$ ed. 1903) or “The Interplanetary Travels" by Y. Perelman.

8 I would also mention A. Rodchenko's photographs and his ideas of the Upper Façade of the city.
} 


\section{Soviet Modernism: architecture as space, building as a border. Establishing the new social order through architecture}

"Main problem of architecture is the delimitation of space with material forms."

M. Ginzburg [8, p. 111]

Architecture as a practice of "setting the borders" is an essentially social field, and after the 1917 Revolution the architects were involved in the transformation of the society and in social engineering. Soviet architects started designing new buildings for the new collectivized lifestyle opposing the old "bourgeois" and atomized one. Commune houses with the collective services were intended to be "The Social Condensers" (according to Constructivist notion) for the new life, the dwellings for the socialist and classless society. Discussing some peculiarities of the new lifestyle one should keep in mind that the living standards in the Imperial Russia were extremely diverse. And the lack of privacy typical of commune house designs would be a disastrous downshifting for the former inhabitants of the middle-class dwellings but would not surprise the workers who used to share the barracks.

The housing designs of the 1920s reveal the totalitarian intentions of Modernism: the architect's intention was to optimize space in order to shape one's lifestyle - that is to control one's life. There were some radical projects regulating all the dwellers' activities to the minute. But even less uncompromising designs like so-called "houses of the transitional type" reflected the same freedom of spatial organization - see, e.g. double-level flats developed by Constructivists. For the target audience who used to live in flats, "horizontally," vertical movement inside the flat was an innovation. The architects' approach was essentially functionalist: the spatial arrangement resulted from the study of movements of the user.

Not only the housing but also all the architectural genres served as a field of spatial experimentation. For instance, the workers' clubs provided architects with enormous grade of flexibility and compositional freedom (in bourgeois society similar part of the "architectural testing ground" played the banker's or artist's mansion). In industrial architecture the new approach resulted in arrangement of the building or the whole ensemble according to the sequence of the stages of production process (see e.g. E. Mendelsohn's design for the Red Banner knitting factory in Leningrad and engineer G. Marsakov's designs for the cylindrical mechanized bakeries). New functional ideas determined enormous diversity of planning and volumetric solutions in the Soviet theatre designs at the turn of the 1920 and 1930s. Composition of a building turned out to be a function of relationships between the audience and the show.

But the $20^{\text {th }}$ century was a century of masses. The masses along with single users and groups were in the focus of architectural design; the masses and their movement determined planning and compositional solutions. The Modernist competitive designs of the theatres as well as some entries submitted for the Palace of Soviets competition (1931) included buildings designed to let masses through. This orientation towards masses remained typical of Stalinist architecture as well: the architectural drawings of the period often represent buildings and ensembles occupied by masses.

So, the changing architects' attitudes and new social circumstances reflected on a scale of an individual building or ensemble. But the focus on the expansion in space resulted also in 
a wide spectrum of large-scale projects ranging from G. Krutikov's imaginary flying cities to "desurbanist" town-planning designs like the linear cities proposed for conversion of huge rural areas 9 .

The part played by architecture in the establishment of the new social order contributed to its interpretation as a field of communication. This vision was rooted in the ideas of speaking architecture of the Enlightenment as well as in "absent patron" issue (mentioned above) when the city dweller needed a predictable and informative environment. The pre-revolutionary architects blamed what they called "the vandalism of advertising." But in the Constructivist designs (like the "iconic" competition entry for the Moscow office of Leningradskaya Pravda by Vesnin Brothers, 1924) one can see building as media transmitting information and political messages. In the Stalinist years designers employed the figurative sculpture - the message appropriate even for the illiterate audience. The main building to be erected in the USSR, the Palace of Soviets in Moscow, set the tone. The permanent propaganda installations with political slogans or illumination served the same purpose.

As a part of the communicative agenda of the Soviet architecture, the issue of visual perception became urgent in the 1920s. Since Modernists ${ }^{10}$ designed their spaces for moving dwellers (for instance, ones driving a car - several decades before Learning from Las Vegas was published), they started experimenting with the expression of form for a moving spectator. For instance, one of the assignments given to the VKhUTEMAS students by N. Ladovsky implied the expression of the form in space for the viewer moving at $15 \mathrm{~m}$ per second. This attitude towards space persisted in the Stalinist bureaucratic empire ${ }^{11}$ and in the post-Stalinist age.

The proponents of Constructivism emphasized the dichotomy of the design method and the architectural style taken as a set of recognizable elements and visual features. The exterior of a building should result from its internal structure (see: [3;11]). But there were also architects who just employed fashionable "signs" of Constructivism instead of optimizing and expressing the interior space. The leading theorist of the movement Ginzburg claimed: "Constructivism was a thousand times not only perverted and vulgarized but also used in an absolutely antithetic way - in a pure formal and aesthetic capacity" [10]. For instance, the glass walls and the ribbon windows providing connection between the interior and the environment were associated with Modernist architecture. Moreover, since the state-of-the-art structural solutions like concrete frame and curtain walls were costly and demanding in terms of standards of construction, the builders often could not afford them. As a result, sometimes we can see conventional brick load-bearing walls with conventional windows within dark strips - so from the distance the building looks like an example of "architecture of Tomorrow."

According to critics, Constructivists ignored very important part of architecture, the emotional one. But as Ginzburg wrote, "The integrity of... Constructivism ${ }^{12}$ is reflected not in the rejection of the emotional impact of the material objects... but in the organization of

\footnotetext{
$9 \quad$ See e.g. "The Green City” by M. Ginzburg and M. Bartsch. One should also mention N. Ladovsky's "parabolic" plan for Moscow.

${ }_{10} \quad$ Both Soviet and Western - see e.g. town planning projects by Le Corbusier.

11 Large-scale spaces like the Red Square depicted on D. Chechulin's design for the high-rise building in Zaryadye (1948) are arranged with the rushing limousines.

12 Mentioned here as a self-denomination of a movement associated with specific architectural group.
} 
this impact in the process of utilitarian and structural shaping of the objects" [11, p. 160]. The theorist states the importance of the "correct taking into account the psycho-physical impact of elements of architecture. The form should not only fulfill its main purpose, but also fulfill it with the maximal clarity and be sensed by our psycho-physical apparatus with minimal loss of the energy of perception" [9, p. 90]. For instance, architects experimented with the color and "faktura" (the wall texture).

The issue of psychology, the issue of visual perception, was a demarcation line between two main movements (and groups) within Soviet Modernism. The architects who identified themselves with Constructivism as a particular group were more focused on functional and structural matters. But, there was also a group of co-called Rationalists (or Formalists, according to their opponents) who were deeply interested in psychology and psychophysiology, in instrumentalization of the emotional effect of architecture. The leader of the group Nikolai Ladovsky was a successful teacher who established his system of spatial propaedeutics at VKhUTEMAS. The curriculum included a course "the Space" led by Ladovsky, who strived for development of the students' skills in expression the forms in space. He even established a lab with devices invented by himself to measure (or reveal) the students' psychophysiological abilities - even though today his experiments are questioned by experts in psychology because of methodological inaccuracy [20].

\section{Formal and spatial propaedeutics of the Soviet Modernism: a success story}

"The design of the architectural work solely on this basis could led (and had led) us in the practice to the abstract creation of forms, to the emasculation of the ideological content which the Soviet art is currently struggling for."

V. Krinsky, I. Lamtsov, M. Turkus [14, p. 6]

And further a success story will be discussed. In the 1920s, Soviet Modernists developed the system of professional thought and architectural values (it couldn't be called theory in every sense of the word) that combined scraps of psychology with the rhetoric of Avant-garde art and even academist practice. This system survived throughout the $20^{\text {th }}$ century and retains its topicality even today.

Let's start with an example.

In 1934, Elements of Architectural and Spatial Composition written by Vladimir Krinsky, Ivan Lamtsov, and Mikhail Turkus was published. This textbook was based on courses dealing with the issues of space, composition, and form, developed by Nikolai Ladovsky and colleagues, and being the propaedeutic basis of the Moscow school of architecture of the 1920s.

In 2011, "Architecture-S" printed another edition of the book titled Three-dimensionalSpatial Composition, first published back in 1993. The authors of the textbook are Alexander Stepanov and his colleagues at the department of Basics of Architectural Design at Moscow Institute of Architecture - a VKhUTEMAS heir. The succession is obvious here. The tools developed back in 1920 were declared universal foundations of the profession. However, the social context, intellectual climate and global architectural landscape have radically changed 
over decades. Nevertheless, in Russia this legacy retains its pedagogical value incomparable to that of the Bauhaus and Le Corbusier legacies in Europe, or ones by (postwar example) Mies and Kahn in the USA etc.

Examining this success story several questions arise: how has the discourse of form become the common way of discussing architecture, how has the Modernist formal propaedeutics become the only shared system of architectural thought, how has the scientistic (or rather pseudoscientistic) concept become nearly the only successful and shared architectural theory in Russia?

What I am going to discuss in this case study is the process of the loss of intellectual independence by the architects. Traditional mechanisms of social functioning of architecture provided by common logic inside and outside the profession were destroyed throughout the 1920s to 1950s. As a result, the universal tool for a Russian architect turned out to be a strange and eclectic system, dating back to formal school of art history with its psychological backgrounds, to "psychological fashion" of the early $20^{\text {th }}$ century, to the ideas of "economy" in visual perception etc.

As mentioned previously, the courses introduced by Ladovsky into pedagogical practice of VKhUTEMAS were focused on psychology and psychophysiology of visual perception, and included assignments implying clear manifestation of forms, programming the viewer's impression building on the "principle of economy of 'psychic energy"' And this focus on formal and spatial matters continued to be relevant even when architecture of Modernism was criticized.

What ensured the establishment of this system?

It reflected common Modernist ideas and implied the instrumentalization of such concepts as space, mass, rhythm, etc ${ }^{13}$. But the fundamental categories of Modernist formalcompositional concept, that is space and mass (and also rhythm), were also typical of general and political discourses. The pathos of expansion and space exploration, declared by the pre-revolutionary Avant-garde and also dissolved in culture, by the early 1930s was cast into formulas such as "we conquer space and time." The word "mass" was also central in the political and professional ${ }^{14}$ discourse. One should also mention the popularity of JaquesDalcroze's eurhythmics and similar practices and concepts.

By setting "psychoanalytic methods," "the principle of economy of psychic energy" at the basis of their school, Modernists continued to follow in line with the "psychological trend" of pre-revolutionary period, which was later galvanized by the upheavals of the First World War. Architects inherited the interest to contemporary psychology and psychophysiology which had been laid in the foundation of the formalist school of art history in the late $19^{\text {th }}$ - early $20^{\text {th }}$ century. They project such ideas (the concept of Heinrich Wölfflin with its psychological undercurrent, ideas of Wilhelm Wundt, the concept of empathy by Wilhelm Worringer) popular before the Revolution into the sphere of architectural methodology. The contacts of Western architecture and psychology have been examined by M. Jarzombek, A. Payne and some other scholars [22], for the Soviet case see works by A. Vronskaya [27], E. Orel [20] et al.

\footnotetext{
13 August Schmarsow is the most important name to be mentioned when discussing this process of changing attitudes towards space (see his theory of Raumgestaltung) [23; 29]. In Russian contexts see e.g. works by A. Gabrichevsky [6] and A. Nekrasov [19].

14 Georgy Lukomsky, for example, while describing new construction in pre-revolutionary Petrograd speaks about the emerging "architecture of the masses" [18].
} 
So Soviet and Post-Soviet architects inherited from the pre-revolutionary period fashionable ideas and values preserved by the Avant-gardists. In the 1920s this trend meets the Soviet fashion for the psychology and the psychophysiology as the means of social engineering; let's mention the popularity of Hugo Münsterberg's psychotechnique, and Ladovsky's experiments were modelled after this example. Ladovsky's "principle of economy" was later criticized as the "idealist fiction," but some traces of this principle might be found even in the Stalinist neoclassicist architecture reflected in the requirement of "simple and easy readability of the architectural image," its accessibility for the mass audience. And the perception of architecture as an art of provoking emotions remained topical throughout the $20^{\text {th }}$ century.

Architectural propaedeutics of Constructivism was a response to the request of the architectural community for an explicitly formulated theory. Architects managed to propose a method and system that looked almost like hard science while being an essentially creative practice (and again, the recent studies have revealed Ladovsky's superficial perception of psychological science). And scientist rhetoric, fashionable in the 1920s, was the container in which the new art was offered to the public and professionals.

In the previous period the techniques of shaping the forms were not the subject of any special reflection - it was a common inherited knowledge. The situation changed in the $1920 \mathrm{~s}$ with the influx of people into the profession, whose educational standards were much lower. However, the demand for positive scientific knowledge and readiness to accept the scientist rhetoric were legacies of the previous period. Catherine Cooke demonstrates examples of prerevolutionary aesthetic works, whose language is borrowed from the fields of science and engineering [4]. And it is this spatial and formal-analytical matter that texts of the 1930s define as the heritage of Modernism, which should be adopted.

Quite significantly the Elements was published in 1934, after the policy of "adopting the heritage" had been launched (1932). Constructivists literally succeeded in catching the outgoing train. Modernism was able to preserve the remainder of the formal thinking system, compositional methods and techniques of shaping the form as an introductory course, officially recommended as a textbook.

Moreover, a new edition was published in 1938. While the 1934 publication involved both historical and modern architecture for illustrations, the authors base new edition "solely on the classics." Just note that in the 1920s the Modernists, for example, Ginzburg, based their concepts on the historical art as well, literally "having adopted the classical heritage" almost a decade before the official sanction ([7;8]). Ginzburg's texts were consistently "wölfflinian." Quite naturally, in the "anti-cosmopolitan" and "antiformalist" texts of the 1940-1950s he will be blamed for following the concepts of "Bergson, Christiansen, Worringer, Riegl and other formalists of the extreme idealist camp" [24, p. 133].

The 1920s were also characterized by the appearance of a variety of "general theories" and "philosophies" of architecture. Even the quite mundane pre-revolutionary "Architectural Orders" by J. Michalowski included an introduction with references to Schopenhauer in the 1925 edition. However, this philosophical claim would leave the architectural discourse in 1930s - philosophy and aesthetics would eventually be "monopolized" by political power.

So, why and how did the Modernist formal-compositional concepts survive after the "turn to the classics?" To answer this question, one should "contextualize" the architectural 
thought of the period and touch upon the main factors that determined the political, cultural, intellectual, and artistic atmosphere of the epoch.

There are two main (and polar) theories describing the establishment of the Stalinist Neoclassicism. The first one was proposed by Vladimir Paperny who developed very convincing and popular model of two opposing cultures - Modernist Culture 1 and Stalinist imperial Culture 2. On the contrary, according to Boris Groys, Stalinist style organically resulted from the development of Avant-garde and was its highest stage.

It seems to be reasonable to talk about a kind of "Culture one and a half," in which the mechanisms of violence were formed back in 1920s while the niches and gaps, providing a kind of pluralism, lasted until the turn of 1940-1950s. On the one hand, the highest level of violence became the norm during First World War, the Revolution and Civil War. The habit of political charges in the architectural debate has also evolved before the "turn to the classics." Arms developed by the Modernists were later turned against themselves. On the other hand, Soviet culture had not been monolithic until the end of the 1940s and there were some niches for Modernists to take refuge in. And the Modernist concepts were reduced to the formal basics and simplest psychological foundations, which made their "survival" easier.

So the emergence of Elements in 1934 is surprising only at first glance.

The essential feature of Stalin's regime is that it was not about absolute uniformity, but a universal and arbitrary nature of violence. The combination of rational motifs of suppression with the irrational and all pervading nature of repression determines the intellectual paralysis of the architectural corporation - but also the existence of the "gaps" in the structure. There were a large number of actors with their own interests, and perhaps the only undisputed factor was the reduced and old-fashioned taste of the customer. And unlike, for example, Nazi Germany, the client's expectations weren't expressed by visual means.

The scientist and psychological rhetoric of Avant-garde was substituted with a comprehensive philosophic and ideological speculation. The architectural discourse, and more broadly the social atmosphere of the 1930s were characterized by demonstrative esoterization of political power. Until that time the existence of architecture was determined by the unity of common logic, allowing an architect to meet his customer's needs. Now the architect can only divine the "brilliant idea" and interpret quite vague instructions. It is the architect who turns out to be "educated" 15.

The 1930-1950s is a period of final loss of professional sovereignty. If earlier the architectural knowledge was the property of architects, now the key to true understanding of "correct relationship of form and content" and to "Socialist Realism" could only be found outside the profession. Therefore the formal problems are relegated to the level of elementary basics of the profession, and the authors suggest as such the course of Krinsky-Lamtsov-Turkus.

15 In 1911 architect R. Beker stated: "It is extremely necessary, that the society should be able to distinguish good architecture from bad architecture; otherwise an architect... will constantly be forced to meet the client's incompetent or even sometimes ridiculous requirements" [2, p. 585]. Compare to A. Vlasov's quote (1935): "The best people, the leaders of the great construction, bring an architect up in his daily work... I am extremely thankful to L. M. Kaganovich who helps me to find the right way in the new life, who shows the place of architecture in this life and leads me as well as all those who are creating the architecture of the beautiful city" $[26$, p. 55]. 
The result is a paradoxical mix of two components within a single architectural discourse: the professional, traditional - and ideological scholasticism. The contemporary readers can split any issue of, e.g., the "Architecture of the USSR" in 1930s into two journals, one of which would consist of political speculation while the other would be the traditional professional edition. This dissolution of discourse is not harmless: with limited resources such as time, creativity and so on, the political demagoguery became a substitute for meaningful activity and intellectually corrupted the architectural corporation.

In an atmosphere of arbitrary violence and arbitrary interpretations, in the absence of a coherent link between "words and things" totalitarianism turns into chaos and gives the architect almost unique freedom (reflected e.g. in the huge diversity of Soviet architecture, and the existence of minimally ideologized texts). Until the turn of 1940-1950s the extent of liberty in Stalinist architecture and discourse was quite high. The degree of ideological demagoguery based directly upon political charges increases dramatically during the "struggle against cosmopolitanism". It seems that the subsequent decline of the Soviet architecture dates back rather to this period with its characteristic injection of patriotic self-admiration and the sealing of culture.

As a result, the qualities of form and composition turned out to be almost the only sovereign sphere for an architect. The Modernist discourse of space, form and composition remained nearly the only reliable intellectual foundation of the profession. There were also some fields demonstrating survival of Modernist formal approach even when Modernism was under a prohibition. Since in the memorial genre the psychological manipulation and provoking viewer's emotions stayed legitimate, memorial projects offered more space for a kind of 'underground' Modernism. One can find some examples as early as the second half of the 1930s and in the projects of monuments to the Soviet-Finnish War. Some impressive Modernist memorial designs of the WWII period were tolerantly accepted by colleagues and the power. These projects demonstrate strong inheritance from the postrevolutionary architecture as if rehabilitating Modernism after almost a decade of the anti-Modernist reaction.

The official language of the Post-Stalinist period also employed the same mainstream discourse of form, as N. Khrushchev's quotation (1954), both classical and modernist, illustrates: "The façades of buildings should be beautiful and attractive thanks to good proportions of the whole building, good proportions of windows and door openings, skillful arrangement of balconies, proper use of the texture and color of the facing materials, true manifestation of wall details and structure..." [28, p. 393]. The conceptual and language continuity was as important as the stylistic, technological, ideological and social shift of the 1950s.

In the wake of the Thaw and the rehabilitation of Avant-garde compositional courses came back into the education system. A Moscow Institute of Architecture textbook was published in 1962 under the title Fundamentals of Architectural Design. A new edition of the Elements was published in 1968. In the following decades the number of publications dedicated to the issues of composition increases constantly. There were also publications on issues of psychology of architecture. The Modernist courses were represented prominently in these textbooks. However, allergic reactions towards philosophy and skepticism about any speculations were inherited from the middle of the century. 
Since recently, the Modernist formal propaedeutics has been reexamined by historians. One should also mention the exhibition Ladovsky's experiment at the Centre of Avant-garde at Shabolovka (2017), curated by Alexandra Selivanova who reconstructed experimental installations developed by Ladovsky at VKhUTEMAS.

But this success story has also had quite negative consequences for the Russian architecture. The considerable part of recently built structures designed by mainstream school architects are of quite low standards in terms of architectural creativity, function, use of materials; they are obsolete and boring. But in terms of formal-compositional discourse they are perfect - wellproportioned, etc. Thus the inherited focus on the issues of form and composition has made architects complacent and self-satisfied. The architectural corporation retains its orientation primarily towards the methods of formal and compositional thinking, which had emerged in 1920s. The humanities, social sciences and philosophy at the school have only been given the status of imposed makeweight for the profession.

\section{References}

1. Bass V. The Discourse of Form as the Last Refuge of the Soviet Architect. Novoe literaturnoe obozrenie (New Literary Observer), 2016, no. 1 (137), pp. 16-38 (in Russian).

2. Beker R. R. Architecture and Society. Trudy IV s"ezda russkikh zodchikh (Proceedings of the $4^{\text {th }}$ Congress of Russian Architects). St. Petersburg, Gosudarstvennaia tipografiia Publ. 1911, pp. 584-590 (in Russian).

3. Cooke C. 'Form is a Function X': The Development of the Constructivist Architect's Design Method. Russian Avant-garde. Art and Architecture. Architectural Design Profile 47, 1983, pp. 34-49.

4. Cooke C. Russian Avant-garde Theories of Art, Architecture and the City. London, Academy Editions Publ., 1995. 208 p.

5. Frankl P. Principles of Architectural History: The Four Phases of Architectural History, 1420-1900. Transl. by J. F. O'Gorman. Boston, Mass., MIT Press Publ., 1982. 239 p.

6. Gabrichevskii A. G. Space and Mass in Architecture (1923). Morfologiia iskusstva (The Morphology of Art). Moscow, Agraf Publ., 2002, pp. 430-447 (in Russian).

7. Ginzburg M. Ia. Ritm v arkhitekture (Rhythm in Architecture). Moscow, Sredi kollektsionerov Publ., 1923. 116 p. (in Russian).

8. Ginzburg M. Ia. Stil' i epokha (The Style and the Epoch). Moscow, Gosudarstvennoe izdatel'stvo Publ., 1924. 238 p. (in Russian).

9. Ginzburg M. Ia. The Functional Method and Form. Sovremennaia arkhitektura (Contemporary Architecture), 1926, no. 4, pp. 89-92 (in Russian).

10. Ginzburg M. Ia. Results and Prospects. Sovremennaia arkhitektura (Contemporary Architecture), 1927, no. 4-5, pp. 112-118 (in Russian).

11. Ginzburg M. Ia. Constructivism as a Method of Laboratory and Pedagogical Work. Sovremennaia arkhitektura (Contemporary Architecture), 1927, no. 6, pp. 160-166 (in Russian).

12. Ginzburg M. Ia. Zhilishche (Dwelling). Moscow, Gosstroiizdat Publ., 1934. 190 p.

13. Grois B. Stil' Stalin. Utopiia i obmen (Stalin Style. Utopia and Exchange). Moscow, Znak Publ., 1993. 373 p. (in Russian).

14. Krinsky V.F.; Lamtsov I. V.; Turkus M.A. Elementy arkhitekturno-prostranstvennoi kompozitsii (Elements of Architectural and Spatial Composition). Moscow; Leningrad, Gosstroiizdat Publ. 1934. 172 p. (in Russian).

15. Ladovskii N. A. On the Role of Space in Architecture and on the Nature of the Synthesis of Architecture, Sculpture, and Painting. 1920. Mastera sovetskoi arkhitektury ob arkhitekture (The Masters of Soviet Architecture on Architecture), vol. 1. Moscow, Iskusstvo Publ., 1975, p. 344 (in Russian).

16. Lamtsov I. V.; Turkus M. A. Ėlementy arkhitekturnoi kompozitsii (Elements of Architectural Composition). Moscow, Leningrad, GONTI Publ., 1938. 168 p. (in Russian). 
17. Ledoux C.-N. L’Architecture considérée sous le rapport de l'art, des mours et de la législation: tome premier. Paris, De l'imprimerie de H.L. Perronneau, 1804. 240 p. (in French).

18. Lukomskii G. K. Sovremennyi Peterburg. Petrograd, Svobodnoe Iskusstvo Publ., 1917. 94 p. (in Russian).

19. Nekrasov A. I. The Given and the Conceived in the Spatial Arts in Terms of Perception of Space. Trudy Sektsii iskusstvoznaniia Instituta arkheologii $i$ iskusstvoznaniia RANION (Proceedings of the Section of Art Studies of the Institute of Archeology and Art Studies RANION), 1928, no. 3, pp. 3-17 (in Russian).

20. Orel E. Otrazhenie psihologicheskoi nauki $v$ traditsii prepodavaniia arkhitektury v SSSR1920-kh godov (Reflection of the Psychological Science in Architectural Education in the USSR in the 1920s), MA Thesis. St. Petersburg, European University at St. Petersburg, Department of Art History Publ., 2017. 81 p. (in Russian).

21. Papernyi V. Kul'tura Dva (Culture Two). Moscow, Novoe literaturnoe obozrenie Publ., 1996. 383 p. (in Russian).

22. Payne A. From Ornament to Object: Genealogies of Architectural Modernism. New Haven, Yale University Press Publ., 2012. 360 p.

23. Schwarzer M.W. The Emergence of Architectural Space: August Schmarsow's Theory of "Raumgestaltung". Assemblage, 1991, no. 15, pp. 48-61.

24. Tsapenko M.P. O realisticheskikh osnovakh sovetskoi arkhitektury (On the Realist Grounds of the Soviet Architecture). Moscow, Gosstroiizdat Publ., 1952. 395 p. (in Russian).

25. Viollet-le-Duc E. E. Discourses on Architecture. Boston, J. R. Osgood and Co Publ., 1875. 517 p.

26. Vlasov A. Creative Work Report. Arkhitektura SSSR (Architecture of the USSR), 1935, no. 4, pp. 55-58 (in Russian).

27. Vronskaya A. The Productive Unconscious: Architecture, Experimental Psychology and the Techniques of Subjectivity in Soviet Russia, 1919-1935, Ph.D. Thesis. Cambridge MA, Massachusetts Institute of Technology, 2014. 405 p.

28. Vsesoiuznoe soveshchanie po stroitel'stvu. Sokrashchennyi steno-graficheskii otchet (Abridged Transcript of the All-Union Building Congress). Moscow, Gosstroiizdat Publ., 1955. 432 p. (in Russian).

29. Zucker P. The Paradox of Architectural Theories at the Beginning of the "Modern Movement". Journal of the Society of Architectural Historians, 1951, vol. 10, no. 3, pp. 8-14.

Title. "Space, Mass, Surface in Architecture": Conceptualization of Spatial Categories and a Building as a Border in Architectural Thought and Practice of the Soviet Constructivism

Author. Vadim Bass - Ph. D., associate professor. European University at St. Petersburg, Gagarinskaya ul., 6/1A 191187 St. Petersburg. Russian Federation. bass@eu.spb.ru

Abstract. In the post-revolutionary years Soviet architects developed new system of professional thought based on the conceptualization of space (and also on the fashion on psychology). This "spatial turn" was common at the beginning of the Modern movement. The very model of the architects' activity and their selfperception changed dramatically: instead of shaping volumes they started "setting the borders" and "organizing" space with surfaces. New focus in Constructivist architecture was reinforced with ideas of expansion and space exploration (popular since the late $19^{\text {th }}$ century) and the "cosmic" vision of Russian Avant-garde art.

The social concern of professional community and the vision of architecture as a field of social interactions contributed to this changing perspective and resulted in new plans and functional arrangement of buildings (e.g. commune houses) as well as new town-planning concepts (linear city, parabolic city). The new grade of flexibility achieved using concrete framework and curtain walls changed the architects' attitudes towards both internal structure and the surface of building.

Soviet architects of the 1920s managed to establish new spatial concept as the pedagogical basis of architectural school, starting from Nikolay Ladovsky's course "Space" at VKhUTEMAS. This system, converted into textbooks on "Volumetric-Spatial Composition," survived in the period of Stalinist anti-Modernist reaction. Even today it lies in foundation of Russian architectural school. The article examines the concept, its sources, establishment, and the reasons for its persistence.

Keywords: Soviet architecture, Constructivism, architectural education, architectural propaedeutics, architectural theory, space in architecture

Название статьи. «Пространство, масса, поверхность в архитектуре»: концептуализация пространственных категорий и здание как граница в архитектурной мысли и практике советского конструктивизма 
Сведения об авторе. Басс Вадим Григорьевич — кандидат искусствоведения, доцент. Европейский университет в Санкт-Петербурге, Гагаринская ул., д. 6/1А, Санкт-Петербург, Российская Федерация, 191187.bass@eu.spb.ru

Аннотация. В послереволюционные годы советские архитекторы разработали новую систему профессионального мышления, основанную на концептуализации пространства (а также на моде на психологию). Этот «пространственный поворот» был общим местом на раннем этапе истории Современного движения. Изменяется сама модель деятельности архитекторов и их профессиональное самосознание: вместо композиции объёмов они начинают «устанавливать границы» и «организовывать пространство» поверхностями. Новые акценты в архитектуре были подкреплены идеями покорения пространства и освоения космоса, популярными с конца XIX столетия, а также «космическим» видением русского авангарда.

Интерес профессионального сообщества к социальной проблематике способствовал этой трансформации и нашёл отражение в новом планировочном и функциональном устройстве зданий (см., напр., дома-коммуны), в новых градостроительных концепциях (линейный город, город-парабола и пр.). Новый уровень свободы, достигнутый благодаря использованию бетонного каркаса и навесных стен, имел следствием изменившееся отношение архитекторов и к внутренней структуре здания, и к его внешнему облику.

Советским архитекторам 1920-х гг. удалось утвердить новую пространственную концепцию в качестве педагогической базы архитектурной школы, начиная с пропедевтического курса Н.А. Ладовского «Пространство» во ВХУТЕМАСе. Эта система, воплотившаяся впоследствии в учебники «Объёмно-пространственной композиции», сохранила легитимность даже в период сталинской антимодернистской реакции. Статья включает обсуждение концепции, её источников, процесса её утверждения и причин её устойчивости.

Ключевые слова: советская архитектура, конструктивизм, архитектурное образование, архитектурная пропедевтика, архитектурная теория, пространство в архитектуре 